\title{
A Study on Clinical Management of Glandular Changes in Cells on Cervical Cytology
}

\author{
Sharadhi Channegowda', Mueed Ijaz², Ayesha Anwar1* \\ ${ }^{1}$ North Cumbria Integrated Care NHS Foundation Trust (NCIC), Carlisle, UK \\ ${ }^{2}$ Kings College, London, UK \\ Email: *ayeshakashif1@hotmail.com
}

How to cite this paper: Channegowda, S., Ijaz, M. and Anwar, A. (2021) A Study on Clinical Management of Glandular Changes in Cells on Cervical Cytology. Open Journal of Obstetrics and Gynecology, 11, 1770-1780. https://doi.org/10.4236/ojog.2021.1112165

Received: November 19, 2021

Accepted: December 20, 2021

Published: December 23, 2021

Copyright $\odot 2021$ by author(s) and Scientific Research Publishing Inc. This work is licensed under the Creative Commons Attribution-NonCommercial International License (CC BY-NC 4.0). http://creativecommons.org/licenses/by-nc/4.0/ (c) (i) (s) Open Access

\begin{abstract}
A cytological cervical smear abnormality of glandular origin raises a high suspicion of underlying invasive or pre invasive cancers. Objective: To look into the diagnosis and management of women presenting with glandular changes on cervical cytology and to further implement a good management plan for these women. Methods: This study is a retrospective review of all patients referred to North Cumbria Integrated Care (NCIC) NHS foundation trust, United Kingdom with glandular changes on their cervical smear result between January 2015 and December 2020. Data was collected from the hospital colposcopy data base. Results: This study comprised of a sample size of 65 women. 11 of these $(17 \%)$ were referred with borderline changes in their endocervical cells and 54 (83\%) referred with a ?glandular neoplasia of endocervical type. There were colposcopically significant lesions (high grade lesions or suspected adenocarcinoma) for $52(80 \%)$ of the women. All but one (98\%) had Large loop excition of transformation zone (LLETZ) after colposcopy. Histologically, 8 (12\%) women were diagnosed with adenocarcinoma, 29 (45\%) were diagnosed with high grade cervical glandular intraepithelial neoplasia (HGCGIN), 9 (14\%) had high grade cervical intraepithelial neoplasia (CIN2/3), 2 (3\%) had low grade cervical glandular intraepithelial neoplasia (LGCGIN), 4 (6\%) had a normal histology and $10(15 \%)$ had lesions of mixed origin. After their first LLETZ treatment, 24 (37.5\%) needed repeat LLETZ, 8 (12\%) had a hysterectomy and one woman had radical trachelectomy.
\end{abstract}

\section{Keywords}

Glandular Changes, Cervical Cytology, Endocervical Cells

\section{Introduction}

A cytological cervical smear abnormality of glandular origin raises a high suspi- 
cion of underlying invasive or pre-invasive disease. The current NHS cervical screening programme triages patients based on high risk Human Papilloma Virus (HPV) positivity. Those who test positive for high risk HPV, with associated cytological abnormalities are immediately referred for colposcopy. The aim of this study was to review the diagnosis and management of those patients with glandular cell abnormalities i.e. borderline changes in their endocervical cells and ?glandular neoplasia of endocervical type on cervical cytology, and their outcome. The terms used in this study, such as borderline change in endocervical cells and ?glandular neoplasia of endocervical type, are based on the description by the British Society for Colposcopy and Cervical Pathology (BSCCP). There have been global inconsistencies in the definition, terminology and classification of abnormalities in glandular cells between various classifications such as Bethesda, BSCCP etc. The Bethesda classifies glandular cells as atypical, atypical and favouring neoplasia and adenocarcinoma in situ, whereas the BSCCP classifies it as a borderline change in endocervical cells, ?glandular neoplasia of endocervical type. For the purpose of this article, the BSCCP terminology will be used [1].

The British Society for Colposcopy and Cervical Pathology (BSCCP) was founded in 1972 to promote high standards of colposcopy and quality assurance [2]. They provide national guidelines for cervical smears and their management. They also facilitate education to professionals providing care for women with cervical and lower genital tract pre-malignant conditions. The society is also involved in the accreditation of colposcopists, promoting research into the screening, diagnosis and prevention of cervical cancer.

The borderline cells of endocervical type show borderline changes in nuclear size, shape and staining properties whereas the term ?glandular neoplasia of endocervical type refers to the fact that there are definite changes in the nucleus and staining suggestive of a probable cancer. Several changes can be seen, such as an irregular nuclear membrane, hyperchromasia, irregular coarse grainy chromatin, changes in the nuclear cytoplasmic ratio and variation in the depth of staining between the cells.

A literature review shows that cervical smears with borderline cells of endocervical type are associated with high incidence of high-grade squamous intraepithelial lesions and invasive disease [3] [4] [5]. However, intraepithelial glandular lesions are detected in less than $10 \%$ of cases [6] [7] [8] [9]. On the other hand, smears with ?glandular neoplasia of endocervical type are associated with high grade glandular premalignant and malignant lesions [6] [10] [11] [12]. This study was designed to assess the diagnosis and management of women presenting to the North Cumbria Integrated Care (NCIC) NHS foundation trust colposcopy services with glandular smear abnormalities, both borderline and those with ?glandular neoplasia of endocervical type.

\section{Objective}

This study was done with an aim to: 
1) To look into the final diagnosis, management and outcome of the women referred to North Cumbria Integratd care (NCIC) colposcopy services with HPV positive smears showing glandular cytological abnormalities.

2) To outline the best clinical approach for management of such cases.

\section{Methods}

This was a retrospective cohort study at the North Cumbria Integrated care (NCIC) NHS foundation trust, United Kingdom conducted between January 2015 and December 2020. The trust provides acute and community based healthcare services to a wide geographic area with a female population of approximately 250,000 , of which 12,400 meet the age criteria to be eligible for screening services. During the study period, 6251 patients were referred from national cervical screening services to the Colposcopy services at NCIC with screening abnormalities.

The colposcopy services at NCIC are run by 6 BSCCP accredited colposcopists, providing 36 clinics in 4-week cycles across two different sites. The service accommodates 9 patients per clinic. The smears from Cumbria are processed in a regional laboratory based in Manchester. Women with glandular smear abnormalities on cytology subsequent to a positive HPV smear are referred for colposcopy as per the national guideline.

The study was registered and approved locally by the Trust Audit department. The hospital database was used to collect demographic data such as: age, parity, menopausal status and current pregnancy status. Information about previous smears was also obtained from the same database. This included information such as previous treatment of the cervix, referring smear result, whether previous smears were up to date and the result of the immediately previous smear test. Colposcopy findings collected included: transformation zone on colposcopy, colposcopic impression, procedure performed at first assessment, LLETZ details and LLETZ margin clearance status. Lastly, other details such as histology, further treatment, further histology results and final diagnosis were obtained. The inclusion criteria included all HPV positive cases referred to NCIC with a smear showing borderline changes in endocervical cells or ?glandular neoplasia of endocervical type between January 2015 to December 2020. There is no exclusion criteria used in the study and all cases which met the inclusion criteria were included in the study. The cytology report given by the pathologist was used in the study and the cytology slides were not reviewed. A chi square test was used to correlate significant disease status (all grades of intraepithelial neoplasia or worse) with age, menopausal status and colposcopic findings. A p value of $<0.05$ was considered as significant. Our study only included data obtained from hospital database and case notes and patients were not followed up in this study.

\section{Results}

A total of 65 women were included in the study. The average age of the women in the study was 34.8 years. The population ranged between 23 and 64 years. Of 
the total sample size, 26 (40\%) were nulliparous, 37 (57\%) were multiparous and 2 (3\%) did not have their parity mentioned in their records. Among the population, 5 (8\%) were postmenopausal, with the rest 60 (92\%) being premenopausal. There were 2 women who had previous treatment on the cervix; one had a punch biopsy and the other had laser vaporization of the cervix. The results of the cervical smears included in the study were distributed as such; 11 (17\%) with borderline changes in endocervical cells and 54 (83\%) with ?glandular neoplasia of endocervical type. The sociodemographic charecteristics are summarised in Table 1.

Sixty four women had a histological diagnosis (one woman did not attend her appointment for LLETZ). There were eight cancers (12\%), 29 (45\%) were diagnosed with high grade cervical glandular intraepithelial neoplasia (HGCGIN), 2 (3\%) had low grade cervical glandular intraepithelial neoplasia (LGCGIN), 9 (14\%) had high grade squamous intraepithelial neoplasia and 10 (15\%) had lesions of mixed origin. Table 2 lists the significant abnormalities in detail.

All patients underwent colposcopic examination at their first visit. On colposcopic assessment, $40(61.5 \%)$ had transformation zone type 1, 17 (26\%) had transformation zone type 2, $5(7.6 \%)$ had transformation zone type 3 and the information about transformation zone was missing in 3 (4.6\%) women. Sixty three (97\%) of the women had LLETZ at their first colposcopy visit, 1 (1.5\%) had single punch biopsy (this patient was referred with a smear of ?glandular neoplasia of endocervical type and on colposcopy, benign changes were found, hence she had a single punch biopsy instead of LLETZ. Her histology was reported as low-grade CGIN. Subsequently, she had a LLETZ and the repeat histology was HGCGIN). 1 (1.5\%) did not agree for LLETZ and did not attend further colposcopy appointments.

On colposcopic examination, 2 (3.2\%) had no abnormality or benign lesions, $6(9.2 \%)$ had unsatisfactory/uncertain colposcopy and 52 (80\%) had significant (intraepithelial neoplasia or worse) colposcopic findings. This is further summarised in Table 3.

Table 1. Sociodemographic features.

\begin{tabular}{cl}
\hline Total number of women in the study & \multicolumn{1}{c}{65} \\
\hline Age & $23-64$ years, Average age 34.8 years \\
& Multiparous 37 (57\%) \\
Parity & Nulliparous 26 (40\%) \\
& Not known 2 (3\%) \\
& Postmenopausal 5 (8\%) \\
Menopausal status & Premenopausal 60 (92\%) \\
& $2(3 \%)$ \\
& $\bullet \quad$ Punch biopsy \\
& $\bullet \quad$ Lazer vaporisation of cervix \\
\hline
\end{tabular}


Table 2. Final Histological diagnosis of the study group.

\begin{tabular}{lcc}
\hline \multicolumn{1}{c}{ Diagnosis } & Frequency & Percentage \\
\hline Cancers: & 8 & 12 \\
Adenocarcinoma & 11 & 17.1 \\
& 2 & 3.1 \\
Squamous Intraepithelial neoplasia: & 4 & 6.2 \\
Cervical Intraepithelial Neoplasia (CIN) 1 & 5 & 7.8 \\
Cervical Intraepithelial Neoplasia 2 & & \\
Cervical Intraepithelial Neoplasia 3 & 31 & 48.4 \\
& 2 & 3.1 \\
Cervical Glandular intraepithelial neoplasia (CGIN): & 29 & 45.3 \\
Low grade Cervical Glandular Intraepithelial Neoplasia & 10 & 15.6 \\
High Grade Cervical Glandular Intraepithelial Neoplasia & 9 & 14 \\
Mixed Intraepithelial neoplasia: & 1 & 1.5 \\
CIN2/3+ High grade CGIN & & 6.2 \\
CIN 1+ High grade CGIN & 4 & 100 \\
No abnormality/HPV only & 64 & \\
Total & & \\
\hline
\end{tabular}

Table 3. Colposcopic findings in study group.

\begin{tabular}{lcc}
\hline \multicolumn{1}{c}{ Colposcopic findings } & Frequency & Percentage \\
\hline Suspected adenocarcinoma & 9 & 13.8 \\
Squamous intraepithelial neoplasia: & 28 & 43 \\
Cervical Intraepithelial Neoplasia High grade & 25 & 38.4 \\
Cervical Intraepithelial Neoplasia low grade & 3 & 4.6 \\
Glandular intraepithelial neoplasia: & & \\
Cervical Glandular Intraepithelial Neoplasia high grade & 11 & 16.9 \\
Mixed intraepithelial neoplasia & 7 & 10.7 \\
Uncertain/unsatisfactory & 6 & 9.2 \\
No abnormality/benign & 2 & 3.1 \\
Others & 2 & 3.1 \\
Total & 65 & 100 \\
\hline
\end{tabular}

There were discrepancies between the cytological, colposcopic and histological findings in 4 cases and their summaries are as follows:

1) Patient had borderline cells of endocervical type, colposcopy showed benign changes. LLETZ was done and histology showed "No HPV".

2) Patient had ?glandular neoplasia of endocervical type, on colposcopy there were some changes but not definite for intraepithelial neoplasia. She had LLETZ done which came back as "HPV only".

3) Patient had ?glandular neoplasia of endocervical type, on colposcopy she had CGIN high grade. Her LLETZ was "HPV only". 
4) Patient had ?glandular neoplasia of endocervical type, on colposcopy she had CIN high grade. Her LLETZ was "HPV only".

A total of 8 women were diagnosed with adenocarcinoma of the cervix. Of them, one had an obvious growth at colposcopy and further investigations revealed a stage $2 \mathrm{~A}$ disease. She underwent a radical surgery (total radical abdominal hysterectomy + bilateral salpingo oophorectomy + ureterolysis and pelvic lymph node dissection). This patient unfortunately had a disease relapse and deceased to the illness 1 year after diagnosis. She was 49 years old and did not have regular smears prior to her referral smear. The second patient with cancer was diagnosed with high grade CGIN on LLETZ. She had 3 LLETZ's with no clear margins and finally had a total laparoscopic hysterectomy and bilateral salpingoophorectomy, the histology of which had a focal area of adenocarcinoma. The third patient had an initial LLETZ showing a HGCGIN without clear margins. She had a further LLETZ which showed adenocarcinoma and she subsequently underwent a total laparoscopic hysterectomy. The summary of all 8 patients diagnosed with cancer is displayed in Table 4.

As a part of their management, 64 (98\%) had LLETZ. Among those, 19 (30\%) had all margins clear, 28 (44\%) with all margins not clear and in 17 (26\%) the margin clearance status for one or more margins was not known.

Second LLETZ procedure was performed in 21/64 (32\%) women. There were 3 women who had 3rd LLETZ (in 3rd LLETZ two women had HGCGIN, one had CIN 3) and one had a vaginal hysterectomy, as three successive LLETZ's did not show clear margins and she had features of high grade CGIN (cervical glandular intraepithelial lesion). The histology of successive LLETZ (second and third) is summarised in Table 5. There was no immediate complication of LLETZ noted in the study. In this study, we did not study the postoperative complications after surgery.

When a chi square test was performed to correlate the disease outcome with age, menopausal status, previous abnormal cytology and previous irregular follow up, it did not reveal any statistically significant correlation. However, a significant colposcopic finding has a statistically significant association pvalue 0.002 ( $\mathrm{p}$ value $<0.05$ ) to the final diagnosis.

Our Unit follows the NHS Cervical Screening Programme NHSCSP guidance [1] for follow up of all treated cases, which is as follows:

If the CGIN has been completely excised at the time of first excision or subsequent re-excision, a test of cure (TOC) sample should be taken six months after treatment. A second TOC sample is taken 12 months later (i.e. 18 months after treatment) if both are negative for High risk HPV, the woman can be discharged to recall in three years. If a positive HPV or cytology result is reported in either of the six or 18 month "TOC" samples, the woman must be referred to colposcopy and managed appropriately. If no colposcopic abnormality is present and re-excision is not appropriate, the woman should revert to ten years of cytology follow up.

Our study did not include follow up data of our cohort. 
Table 4. Summary of patients with adenocarcinoma.

\begin{tabular}{|c|c|c|c|c|c|c|}
\hline Age & Referral smear & $\begin{array}{l}\text { Previous } \\
\text { smear }\end{array}$ & $\begin{array}{l}\text { Colposcopy } \\
\text { findings }\end{array}$ & $\begin{array}{l}\text { First treatment \& } \\
\text { Histology }\end{array}$ & $\begin{array}{c}\text { Further } \\
\text { treatment \& histology }\end{array}$ & Summary \\
\hline 49 year & $\begin{array}{l}\text { ?Glandular } \\
\text { neoplasia of } \\
\text { endocervical type }\end{array}$ & $\begin{array}{l}\text { Not up } \\
\text { to date } \\
3\end{array}$ & $\begin{array}{l}\text { Suspected } \\
\text { adenocarcinoma }\end{array}$ & $\begin{array}{l}\text { LLETZ } \\
\text { Adenocarcinoma } \\
\text { stage } 2 \text { A on first } \\
\text { LLETZ }\end{array}$ & $\begin{array}{l}\text { Radical surgery } \\
\text { (Total abdominal } \\
\text { hysterectomy + } \\
\text { bilateral salpingo } \\
\text { oophorectomy+ } \\
\text { ureterolysis and } \\
\text { pelvic lymph } \\
\text { node dissection) }\end{array}$ & $\begin{array}{l}\text { LLETZ x1 } \\
\text { Deceased } \\
\text { to the } \\
\text { illness }\end{array}$ \\
\hline 33 year & $\begin{array}{l}\text { ?Glandular } \\
\text { neoplasia of } \\
\text { endocervical type }\end{array}$ & 2 & CIN High grade & $\begin{array}{l}\text { LLETZ } \\
\text { Adenocarcinoma } \\
\text { stage } 1 \mathrm{~A}\end{array}$ & $\begin{array}{l}\text { Total laparoscopic } \\
\text { hysterectomy }\end{array}$ & LLETZ $x 1$ \\
\hline 34 year & $\begin{array}{l}\text { ?Glandular } \\
\text { neoplasia of } \\
\text { endocervical type }\end{array}$ & 2 & $\begin{array}{l}\text { CIN+ CGIN High } \\
\text { grade }\end{array}$ & $\begin{array}{l}\text { LLETZ } \\
\text { 1) HGCGIN } \\
\text { 2) Adenocarcinoma } \\
\text { stage 1A on second } \\
\text { LLETZ }\end{array}$ & $\begin{array}{l}\text { Total laparoscopic } \\
\text { Hysterectomy }\end{array}$ & $\begin{array}{l}\text { LLETZ } \\
\mathrm{X} 2\end{array}$ \\
\hline 29 year & $\begin{array}{l}\text { ?Glandular } \\
\text { neoplasia of } \\
\text { endocervical type }\end{array}$ & 2 & CGIN High grade & $\begin{array}{l}\text { LLETZ } \\
\text { 1) HGCGIN } \\
\text { 2) Adenocarcinoma } \\
\text { stage 1B1 on second } \\
\text { LLETZ }\end{array}$ & $\begin{array}{l}\text { Radical } \\
\text { Trachylectomy }\end{array}$ & LLETZ x2 \\
\hline 47 year & $\begin{array}{l}\text { ?Glandular } \\
\text { neoplasia of } \\
\text { endocervical type }\end{array}$ & $\begin{array}{l}\text { Not up to } \\
\text { date } \\
2\end{array}$ & $\begin{array}{l}\text { Suspected } \\
\text { adenocarcinoma }\end{array}$ & $\begin{array}{l}\text { LLETZ } \\
\text { 1) HGCGIN } \\
\text { 2) Adenocarcinoma } \\
\text { stage 1A on } \\
\text { hysterectomy } \\
\text { specimen }\end{array}$ & $\begin{array}{l}\text { Total laparoscopic } \\
\text { hysterectomy }+ \\
\text { Bilateral } \\
\text { salpingo ophorectomy }\end{array}$ & $\begin{array}{l}\text { LLETZ } \\
\mathrm{X} 1\end{array}$ \\
\hline 35 year & $\begin{array}{l}\text { ?Glandular } \\
\text { neoplasia of } \\
\text { endocervical type }\end{array}$ & $\begin{array}{l}\text { Not up to } \\
\text { date } 2\end{array}$ & $\begin{array}{l}\text { High grade CIN+ } \\
\text { suspected } \\
\text { adenocarcinoma }\end{array}$ & $\begin{array}{l}\text { LLETZ } \\
\text { 1) HGCGIN } \\
\text { 2) Adenocarcinoma } \\
\text { stage 1A on } \\
\text { hysterectomy } \\
\text { specimen }\end{array}$ & $\begin{array}{l}\text { Total laparoscopic } \\
\text { hysterectomy }\end{array}$ & $\begin{array}{l}\text { LLETZ } \\
\mathrm{X} 1\end{array}$ \\
\hline 30 year & $\begin{array}{l}\text { ?Glandular } \\
\text { neoplasia of } \\
\text { endocervical type }\end{array}$ & 2 & $\begin{array}{l}\text { High grade } \\
\text { CIN+ suspected } \\
\text { adenocarcinoma }\end{array}$ & $\begin{array}{l}\text { LLETZ } \\
\text { 1) HGCGIN } \\
\text { 2) Adenocarcinoma } \\
\text { stage 1A on } \\
\text { hysterectomy } \\
\text { specimen }\end{array}$ & $\begin{array}{l}\text { Total laparoscopic } \\
\text { hysterectomy }\end{array}$ & $\begin{array}{l}\text { LLETZ } \\
\mathrm{X} 1\end{array}$ \\
\hline 41 year & $\begin{array}{l}\text { ?Glandular } \\
\text { neoplasia of } \\
\text { endocervical type }\end{array}$ & $\begin{array}{l}\text { Not up to } \\
\text { date } \\
2\end{array}$ & $\begin{array}{l}\text { Suspected } \\
\text { adenocarcinoma }\end{array}$ & $\begin{array}{l}\text { LLETZ } \\
\text { 1) HGCGIN } \\
\text { 2) Adenocarcinoma } \\
\text { on hysterectomy } \\
\text { specimen }\end{array}$ & $\begin{array}{l}\text { Total laparoscopic } \\
\text { hysterectomy }\end{array}$ & $\begin{array}{l}\text { LLETZ } \\
\text { X3 }\end{array}$ \\
\hline
\end{tabular}


Table 5. Successive LLETZ diagnosis.

\begin{tabular}{lcc}
\hline \multicolumn{1}{c}{ Diagnosis } & Frequency & Percentage \\
\hline No abnormality & 13 & 54.1 \\
Cervical intraepithelial neoplasia & 7 & 29.1 \\
High Grade Cervical Glandular & 3 & 12.5 \\
Intraepithelial Neoplasia & 1 & 4.1 \\
Adenocarcinoma & 24 & 100 \\
Total & & \\
\hline
\end{tabular}

\section{Discussion}

Due to inconsistent terminology, the majority of the cases in literature are based on atypical glandular cells on cytology. A literature search revealed significant histological abnormalities in between $17 \%$ and $50 \%$ of the cases, with most of them being of squamous origin [5] [11] [13] [14]. In our study, 93.7\% of the women were found to have histologically significant abnormalities; $12 \%$ had adenocarcinoma, 45\% with HGCGIN, 17\% CIN, 3\% LGCGIN and 15.6\% with mixed lesions. A large variation in the proportion and nature of histological abnormalities is likely due to two main reasons. The first being inconsistencies in the definition, terminology and classification of abnormalities in glandular cells between various classifications. The second reason being that our study has taken both cytologies i.e. borderline change of endocervical cells and ?glandular neoplasia of endocervical type. The terminology of atypical glandular cells of undetermined significance in the Bethesda system of classification corresponds to borderline change in endocervical cells in BSCCP classification. Similarly, atypical glandular cells favouring neoplasia corresponds to ?glandular neoplasia of endocervical type. The incidence of cervical adenocarcinoma with glandular cell abnormalities ranges from $1.4 \%$ to $18 \%$ [15]. In our study, this has been calculated as $12 \%$. The abnormal glandular cells can arise from various malignancies such as cervical adenocarcinoma, endometrial carcinoma and metastatic carcinoma from the ovaries, colon or other abdominal organs. In our review, all cancers in our study were from cervical origin.

The cytology result with ?glandular neoplasia is associated with $17 \%$ to $96 \%$ of premalignant or malignant pathology [6] [10] [11] [12]. Similarly, those with borderline cytologies are closely linked to high-grade squamous intraepithelial lesions in $27 \%$ to $37 \%$ of cases and invasive disease in $1.8 \%$ to $22 \%$ of cases. Intraepithelial glandular lesions are detected in less than $10 \%$ of cases [6] [7] [8] [9]. In our study, $45 \%$ had HGCGIN, $17 \%$ had CIN, $3 \%$ had low grade CGIN and $15.6 \%$ had mixed lesions. In comparison to the review article by Juliana Pedrosa de Holanda Marques et al., which found $42 \%$ and $43 \%$ benign and premalignant histologies respectively [16], our study found $6.25 \%$ benign and $81.2 \%$ pre-malignant histologies. Several articles have published a variety of management plans due to the differing national recommendations at that point in time, as well as there being local variations in different units when it comes to man- 
agement. In our study, women with significant findings in colposcopy were offered a LLETZ procedure. We found that colposcopy was the most significant predictor of pre-invasive and invasive cervical disease ( $\mathrm{P}$ value being 0.002). Based on our study, we would recommend the use of LLETZ with the first colposcopy if it was associated with significant findings. It is worth noting that despite $97 \%$ of cases having an LLETZ at first visit, $32.8 \%$ of them needed a second LLETZ and $4.6 \%$ of them needed a third LLETZ before they were followed up with surveillance cytologies. One patient needed a vaginal hysterectomy, as even after the third LLETZ procedure, no clear margins were seen. This emphasises the extent of morbidity that can be associated with a glandular abnormality on cervical cytology.

A study by Jiangrong Wang et al. showed that the risk of developing cervical adenocarcinoma in those who had atypical glandular cells in the past increases up to 15 years even after treatment [15]. Hence, the LLETZ procedure recommended by BSCCP was followed in our study, which is as follows: The depth of LLETZ in younger women and/or women who wish to conserve their fertility who have a colposcopically visible squamocolumnar junction (SCJ), a cylindrically-shaped cervical excisional biopsy, including the whole transformation zone (TZ) and at least $1 \mathrm{~cm}$ of endocervix above the SCJ is appropriate. In older women, or where the SCJ is not visible at colposcopy, a cylindrical biopsy should be taken that includes all of the visible TZ and $20 \mathrm{~mm}$ to $25 \mathrm{~mm}$ of the endocervical canal. This is because older women have a higher chance of having skip lesions but $95 \%$ of CGIN extends within $25 \mathrm{~mm}$ of the anatomical external os [17].

Lobular endocervical glandular hyperplasia (LEGH) of the cervix is a rare falsely neoplastic lesion of the cervix. They resemble the pyloric glands of the stomach. Most of the times they are found incidentally and may resemble glandular intraepithelial neoplasia of the cervix clinically and radiologically [18]. There are some studies which show a link between LEGH and HGCGIN and gastric type mucinous adenocarcinoma [19], however there has not been enough evidence to prove this. Gastric type mucinous endocervical adenocarcinoma (GAC) of cervix are rare type of adenocarcinomas and are very aggressive with a very high rate of recurrence even after treatment [20]. Both LEGH and GAC are not associated with HPV virus. Our study included only HPV positive cases with glandular lesions. Hence we have not come across LEGH or GAC in our study.

Based on this study we suggest a management plan as follows:

1) All cytologies with glandular cell abnormalities should be referred for colposcopy.

2) If a high grade lesion is suspected on colposcopy LLETZ should be performed.

3) If the squamocolumnar junction cannot be seen clearly then LLETZ should be performed.

4) If margins from the LLETZ sample are not clear, a repeat LLETZ is preferred over surveillance. 
5) When successive LLETZ samples (three) do not show clear margins, and a further LLETZ is not possible, a hysterectomy should be advised if her family is complete.

\section{Conclusion}

Our study concluded that a significant $15 \%$ (8 out of 54) of all women referred with a smear showing ?glandular neoplasia were found to have adenocarcinoma of the cervix. None of the patients with borderline smear of endocervical type had cancer. Considering a high potential of morbidity and mortality in those with abnormal glandular cytology, careful consideration must be taken during diagnosis and management of such cases. In most cases, a histological diagnosis is recommended, unless the cervix looks normal on satisfactory colposcopy. The cases with discrepancy between cytology and histology should be discussed and reviewed in the multidisciplinary setting.

\section{Conflicts of Interest}

The authors declare no conflicts of interest.

\section{References}

[1] The British Society for Colposcopy and Cervical Pathology (2016) NHS Cervical Screening Programme Colposcopy and Programme Management. NHSCSP Publication No. 20, 3rd Edition, Public Health England, London.

https://www.bsccp.org.uk/assets/file/uploads/resources/NHS Cervical Screeing_Pr ogramme. Publication Number 20 - Third Edition.pdf

[2] The British Society for Colposcopy and Cervical Pathology (n.d.). https://www.bsccp.org.uk/

[3] Lee, K.R., Manna, E.A. and St John, T. (1995) Atypical Endocervical Glandular Cells: Accuracy of Cytologic Diagnosis. Diagnostic Cytopathology, 13, 202-208. https://doi.org/10.1002/dc.2840130305

[4] Korn, A.P., Judson, P.L. and Zaloudek, C.J. (1998) Importance of Atypical Glandular Cells of Uncertain Significance in Cervical Cytologic Smears. Journal of Reproductive Medicine, 43, 774-778.

[5] Zweizig, S., Nollar, K., Reale, F., Collis, S. and Resseguie, L. (1997) Neoplasia Associated with Atypical Glandular Cells of Undetermined Significance on Cervical Cytology. Gynecologic Oncology, 65, 314-318. https://doi.org/10.1006/gyno.1997.4640

[6] Cullimore, J. and Scurr, J. (2000) The Abnormal Glandular Smear: Cytological Prediction, Colposcopic Correlation and Clinical Management. Journal of Obstetrics and Gynaecology, 20, 403-407. https://doi.org/10.1080/01443610050112075

[7] Mohammed, D.K., Lavie, O., de B Lopes, A., Cross, P. and Monaghan, J.M. (2000) A Clinical Review of Borderline Glandular Cells on Cervical Cytology. BJOG, 107, 605-609. https://doi.org/10.1111/j.1471-0528.2000.tb13300.x

[8] Jadoon, B.A., Kehoe, S., Romain, K., Clelland, C. andSundar, S.S. (2009) Analysis of Outcome in Women with Borderline Glandular Change on Cervical Cytology. European Journal of Obstetrics \& Gynecology and Reproductive Biology, 147, 83-85. https://doi.org/10.1016/j.ejogrb.2009.07.007

[9] Patel, A., Thampy, N., Hemming, D. and Naik, R. (2010) A Clinical Review of Bor- 
derline Glandular Cells Reported on Liquid-Based Cervical Cytology. BJOG, 117, 1051-1059. https://doi.org/10.1111/j.1471-0528.2009.02477.x

[10] Leeson, S.C., Inglis, T.C.M. and Salman, W.D. (1997) A Study to Determine the Underlying Reason for Abnormal Glandular Cytology and the Formulation of a Management Protocol. Cytopathology, 8, 20-26. https://doi.org/10.1046/j.1365-2303.1997.43175431.x

[11] Jackson, S.R., Hollingworth, T.A., Anderson, M.C., Johnson, J. and Hammond, R.H. (1996) Glandular Lesions of the Cervixcytological and Histological Correlation. $C y$ topathology, 7, 10-16. https://doi.org/10.1046/j.1365-2303.1996.37382373.x

[12] Laverty, C.R., Farnsworth, A., Thurloe, J. and Bowditch, R. (1988) The Reliability of a Cytological Prediction of Cervical Adenocarcinoma in Situ. Australian and New Zealand Journal of Obstetrics and Gynaecology, 28, 307-312.

https://doi.org/10.1111/j.1479-828X.1988.tb01688.x

[13] Kennedy, A.W., Salmieri, S.S., Wirth, S.L., Biscotti, C.V., Tuason, L.J. and Traverca, M.J. (1996) Results of the Clinical Evaluation of Atypical Glandular Cells of Undetermined Significance (AGCUS) Detected on Cervical Cytological Screening. Gynecologic Oncology, 63, 14-18. https://doi.org/10.1006/gyno.1996.0270

[14] Duska, L.R., Flynn, C.F. and Chen, A., Whall-Strojwas, D. and Goodman, A. (1998) Clinical Evaluation of Atypical Glandular Cells of Undetermined Significance on Cervical Cytology. Obstetrics \& Gynecology, 91, 278-282. https://doi.org/10.1016/S0029-7844(97)00659-5

[15] Wang, J., Andrae, B., Sundström, K., Ström, P., Ploner, A., Miriam Elfström, K., et al. (2016) Risk of Invasive Cervical Cancer after Atypical Glandular Cells in Cervical Screening: Nationwide Cohort Study. BMJ, 352, Article No. i276. https://doi.org/10.1136/bmj.i276

[16] Marques, J., Costa, L., Pinto, A., de Lima, A., Duarte, M., Barbosa, A. and Medeiros, P. (2011) Atypical Glandular Cells and Cervical Cancer: Systematic Review. Revista da Associação Médica Brasileira, 57, 234-238. https://doi.org/10.1590/S0104-42302011000200024

[17] Bertrand, M., Lickrish, G.M. and Colgan, T.J. (1987) The Anatomic Distribution of Cervical Adenocarcinoma in Situ: Implications for Treatment. American Journal of Obstetrics \& Gynecology, 157, 21-25. https://doi.org/10.1016/S0002-9378(87)80338-1

[18] Mikami, Y., Hata, S., Melamed, J., Fujiwara, K. and Manabe, T. (2001) Lobular Endocervical Glandular Hyperplasia Is a Metaplastic Process with a Pyloric Gland Phenotype. Histopathology, 39, 364-372.

https://doi.org/10.1046/j.1365-2559.2001.01239.x

[19] Liao, S.Y., Rodgers, W.H., Kauderer, J., Darcy, K.M., Carter, R., Susumu, N., et al. (2013) Endocervical Glandular Neoplasia Associated with Lobular Endocervical Glandular Hyperplasia Is HPV-Independent and Correlates with Carbonic Anhydrase-IX Expression: A Gynaecological Oncology Group Study. British Journal of Cancer, 108, 613-620. https://doi.org/10.1038/bjc.2012.578

[20] Park, C.M., Koh, H.M., Park, S., Kang, H.S., Shim, S.S. and Kim, S.Y. (2018) Gastric Type Mucinous Endocervical Adenocarcinoma of the Uterine Cervix: Very Rare and Interesting Case. Obstetrics \& Gynecology Science, 61, 165-169.

https://doi.org/10.5468/ogs.2018.61.1.165 